\title{
WARUNKI MIKROKLIMATYCZNE WE WNĘTRZU BORU SOSNOWEGO NA MIERZEI ŁEBSKIEJ
}

\author{
LESZEK KOLENDOWICZ, EWA BEDNORZ
}

\author{
Zakład Klimatologii, Instytut Geografii Fizycznej i Kształtowania Środowiska Przyrodniczego, \\ Uniwersytet im. Adama Mickiewicza
}

\begin{abstract}
The observed regularities concerning the differentiation of the temperature of individual layers of the pine forest point to the assumption by the tree crowns of the role of the active surface, which is served by the soil surface in the area devoid of vegetation. This is supported among others by the higher values of air temperature to a height of $6 \mathrm{~m}$ above ground level between 12.00-15.00 hours, this means during the maximum of the intensity of solar radiation (Molga 1970). Moreover the lowest values of air temperature appears to a bottom part of the pine forest above ground level between 15.00-8.00 hours. The inversion of temperature near the ground is a natural phenomenon in the night hours, particularly at dawn. If no compact vegetation layer is present, it comes into being during calm nights and in the predawn hours above the active surface (above the ground) due to the radiation of heat from the ground zone to higher layers of the atmosphere. Appearance of the cool layer in the bottom part of pine forest under the hight of 6-8 $\mathrm{m}$ above ground level during the points to the assumption of the role of the active surface by pine crowns at this very height (Molga 1970; Paszyński et al. 1999).
\end{abstract}

Differences in temperature between the open area and the forest interior or the layer of air above the forest point to the differentiation of energy exchange processes, this being dependent on the nature of the active surface. The forest area is characterised by a clearly lower albedo value than the area of the grey sand dune upon which the MAWS 201 station is located. In addition, forest areas may accumulate a greater amount of heat during the day than the sandy soil covered with grassy vegetation. The stored heat, the quantity of which depends both on the heat capacity and the albedo value, is transferred to the atmosphere in the night. Thus, the layer of atmosphere above the forest is usually warmer at night than the air located above the ground not covered with dense and tall vegetation. During the day, the soil is considerably warmer than the active surface of the forest, which results from the lower heat capacity of the soil. For this reason, a considerably greater quantity of energy radiates in a longwave form than in the case of the forest, and thus the temperature of air above the ground during the day is higher (Paszyński et al. 1999). During the day, the interior of the forest is in turn cooler than the areas devoid of vegetation due to considerably weaker solar radiation reaching the forest bed. At night, however, due the emission of additional quantities of heat from the tall vegetation and the more difficult emission of energy from the forest soil to the atmosphere above the forest (due to its absorption by the vegetation), the temperature of air inside the forest is usually higher than in the area devoid of vegetation (Geiger 1942; Molga 1970).

The distribution of humidity in individual layers of the researched forest community does not differ considerably from the results of research carried out on this topic by other authors. The greater content of water vapour in the air inside the forest in comparison with the open area results directly from the considerable intensity of evaporation of the lower active surface of the forest. The maintenance of the greatest air humidity in the lower zone of pine crowns is most probably connected with their additional transpiration (apart from the transpiration of vegetation of the forest bed) and low wind velocities, which make it possible for water vapour to gather and remain in this zone (Molga 1970).

Keywords: Słowiński National Park, pine forest, microclimate 


\section{WSTĘP}

Do tej pory na Mierzei Łebskiej prowadzono szereg prac badawczych o charakterze klimatologicznym. Zbadano między innymi zmienność termiczno-wilgotnościową w wybranych typach ekosystemów (Kolendowicz 2002; Rabski 1987), opublikowano prace omawiające zagadnienie zmienności w ciągu doby prędkości i kierunku wiatru (Bogucki 1994; Tamulewicz 2002). Zagadnieniami bioklimatycznymi na omawianym obszarze zajęła się Medzińska (1991), przedstawiając zmienność wielkości ochładzającej powietrza. Przeprowadzono również analizę uwarunkowań synoptycznych silnych opadów atmosferycznych w okresie letnim (Kolendowicz i in. 2004). Dokonano także badań typów topoklimatu na Mierzei Łebskiej (Bednorz i in. 2001) oraz zajmowano się zagadnieniami mezoklimatycznymi (Rabski 1992). W roku 2008 dokonano badań mikroklimatycznych pozwalających na określenie zmienności dobowej temperatury i wilgotności powietrza wewnątrz boru sosnowego. Stanowisko pomiarowe usytuowano około $15 \mathrm{~m}$ od skraju boru (Kolendowicz, Bednorz 2009). Mikroklimat obszarów leśnych różni się w znaczący sposób od klimatu obszarów otaczających. Główną przyczyną zróżnicowania jest osłabianie przez korony drzew przenikającego do wnętrza lasu promieniowania słonecznego. $Z$ reguły do najważniejszych stref klimatycznych wewnątrz zbiorowisk leśnych zalicza się: wierzchnią warstwę gleby leśnej, przygruntową warstwę powietrza oraz strefę koron. Zróżnicowanie klimatyczne wyróżnionych pięter zależy od wielu czynników lokalnych, takich jak wiek i gęstość drzew, ich skład gatunkowy czy od warunków makroklimatycznych.

$\mathrm{Z}$ warstwą koron i przygruntową warstwą powietrza związane są dwie powierzchnie czynne obszarów leśnych - dolna i górna. W zależności od gęstości zadrzewienia wspomniane powierzchnie czynne w różnym stopniu biorą udział w wymianie energii i materii pomiędzy obszarem leśnym i atmosferą. W przypadku lasu gęstego rolę powierzchni czynnej przejmują korony drzew, absorbując większość promieniowania krótkofalowego Słońca i redukując znacznie rolę dolnej powierzchni czynnej. W drzewostanie rzadkim rolę powierzchni czynnej przejmuje powierzchnia gleby (Molga, 1970; Radomski 1977). Położenie powierzchni czynnej wpływa znacząco na warunki oświetleniowe, a tym samym na termiczne i wilgotnościowe panujące w lesie. W okresie lata w dzień wewnątrz obszarów leśnych panuje z reguły niższa temperatura i wyższa wilgotność niż na przestrzeni otwartej. Największą wilgotność notuje się z kolei w koronach drzew. Wiatr wyhamowywany przez roślinność charakteryzuje się zdecydowanie mniejszą prędkością niż w terenie otwartym. Obecność wysokiej szaty roślinnej wpływa również na temperaturę gruntu, grubość i długość zalegania pokrywy śnieżnej oraz ilość wody docierającej do powierzchni gleby (Ceitel 1985; Chromow 1969; Lewińska 2000; Łukasiewicz 2005). 


\section{CEL OPRACOWANIA I METODY BADAŃ}

Celem opracowania było zbadanie stratyfikacji klimatycznej zbiorowisk leśnych na przykładzie boru sosnowego, pokrywającego znaczne obszary środkowej części Mierzei Łebskiej, i porównanie uzyskanych rezultatów z warunkami atmosferycznymi panującymi na przestrzeni otwartej w ich sąsiedztwie. Praca jest kontynuacją badań mikroklimatu boru sosnowego prowadzonych przez pracowników Zakładu Klimatologii IGFiKŚP UAM na Mierzei Łebskiej.

W pomiarach terenowych prowadzonych od 2 lipca do 21 sierpnia $2009 \mathrm{r}$. wykorzystano pięć rejestratorów temperatury i wilgotności powietrza typu HOBO, umieszczając je w profilu pionowym na wysokościach $1,5 \mathrm{~m}, 4 \mathrm{~m}$, $6 \mathrm{~m}, 8 \mathrm{~m}$ i $10 \mathrm{~m}$ n.p.g. w borze sosnowym. Punkt położony $10 \mathrm{~m} \mathrm{n.p.g.} \mathrm{znaj-}$ dował się na górnej granicy koron drzew, trzy niżej zlokalizowane punkty usytuowano wewnątrz korony sosny, a czwarty ponad roślinnością dna lasu. Wymienione punkty umieszczono wewnątrz boru sosnowego w odległości $350 \mathrm{~m}$ od linii brzegowej Morza Bałtyckiego. Pomiędzy skrajem boru a wydmą białą oddzielającą obszar badań od plaży nadmorskiej usytuowano automatyczną stację meteorologiczną MAWS 201. Stacja dokonywała pomiarów temperatury i wilgotności powietrza na standardowej wysokości $2 \mathrm{~m}$ n.p.g., prędkości i kierunku wiatru oraz natężenia promieniowania Słońca. Odległość stacji od brzegu lasu wynosiła około $50 \mathrm{~m}$. Za pomocą rejestratorów HOBO dokonano pomiaru temperatury i wilgotności powietrza na wszystkich wymienionych wysokościach profilu pionowego. Stacja automatyczna położona poza lasem dostarczyła informacji o temperaturze i wilgotności powietrza oraz prędkości wiatru. Pomiary prowadzono z godzinnym interwałem czasowym. Porównując warunki atmosferyczne panujące wewnątrz badanego zbiorowiska roślinnego i na przestrzeni otwartej, posłużono się uśrednionymi przebiegami badanych elementów meteorologicznych dla doby z całego okresu pomiarowego oraz dla doby średniej charakteryzującej się występowaniem pogody radiacyjnej. Pogoda o charakterze radiacyjnym, z niewielkimi prędkościami wiatru i małym zachmurzeniem nieba, powoduje występowanie maksymalnego natężenia strumieni materii i energii pomiędzy powierzchnią czynną i atmosferą. Fakt ten w znacznym stopniu wpływa zarówno na wartości elementów meteorologicznych, jak również na większe ich zróżnicowanie zależne od rodzaju powierzchni czynnej (Paszyński i in. 2001). Wyróżnienie dni z pogodą radiacyjną pozwala zatem na uchwycenie największego zróżnicowania termiczno-wilgotnościowego wewnątrz zbiorowiska boru sosnowego oraz różnic pomiędzy wnętrzem boru i przestrzenią otwartą. Obliczenia przeprowadzone dla całego okresu badań dają z kolei obraz średnich warunków meteorologicznych panujących w okresie lata wewnątrz obszarów leśnych, jak i na przestrzeni otwartej w środkowej części Mierzei Łebskiej. 


\section{REZULTATY BADAŃ}

$\mathrm{Na}$ wstępie dokonano analizy uśrednionych warunków pogodowych panujących w okresie pomiarowym od 2 lipca do 21 sierpnia 2009 r. oraz średnich warunków atmosferycznych charakterystycznych dla doby z pogodą radiacyjną.

Dla doby średniej całkowite promieniowanie Słońca wynosiło $0 \mathrm{~W} \cdot \mathrm{m}^{-2}$ w godzinach od 21.00 do 06.00 . Od 6.00 do 12.00 jego wartości rosną osiągając maksimum wynoszące ponad $460 \mathrm{~W} \cdot \mathrm{m}^{-2}$ pomiędzy południem a godziną 14.00 , po czym zmniejszają się do $0 \mathrm{~W} \cdot \mathrm{m}^{-2} \mathrm{o} 21.00$.

Dni z pogodą radiacyjną charakteryzują się natomiast większymi maksymalnymi wartościami promieniowania całkowitego osiągającymi niemal $600 \mathrm{~W} \cdot \mathrm{m}^{-2}$ dla godzin okołopołudniowych (ryc. 1).

Średnia temperatura powietrza $\mathrm{w}$ badanym okresie była najniższa w nocy, z minimum około godziny 5.00 wynoszącym $15,0^{\circ} \mathrm{C}$. Najwyższe wartości temperatury $\left(21^{\circ} \mathrm{C}\right)$ notowano od godziny 14.00 do 15.00 . Średnia dobowa amplituda temperatury powietrza wynosiła $6^{\circ} \mathrm{C}$. Dni z pogodą radiacyjną charakteryzowały się większą amplitudą dobową $\left(8^{\circ} \mathrm{C}\right)$ wynikającą z wyższych niż w dobie średniej wartości temperatury powietrza w godzinach okołopołudniowych $\left(23^{\circ} \mathrm{C}\right.$ o godzinie 14.00) (ryc. 2).

Przebieg średniej wilgotności względniej powietrza w ciągu doby charakteryzuje się występowaniem maksymalnych wartości w nocy od godziny 23.00 do 6.00 , kiedy wilgotność wynosi około $88 \%$ i minimalnych wartości pomiędzy 12.00 a 16.00 (ok. 70\%). Większe zróżnicowanie wilgotności względnej powietrza występuje w dniach z pogodą radiacyjną. Od godziny 0.00 do 6.00 charakterystyczna największa wilgotność wynoszącą niemal $90 \%$, natomiast najmniejsze wartości (ok. 67\%) osiąga w godzinach od 13.00 do 14.00, w dniach z pogodą radiacyjną (ryc. 2).

Prędkość wiatru w ciągu doby charakteryzuje się wyraźną cyklicznością zarówno dla doby średniej z całego okresu pomiarowego, jak również w dniach $\mathrm{z}$ pogodą radiacyjną. Niewielkie prędkości wiatru występują w godzinach nocnych od 21.00 do 7.00. Po tym okresie odnotowujemy jej wzrost do godziny 12.00. Maksimum prędkości wiatru wystąpiło pomiędzy godziną 14.00 i 17.00. Dla doby średniej prędkości wiatru nocą wynoszą około $1,5 \mathrm{~m} \cdot \mathrm{s}^{-1}$ a w dzień ponad $3 \mathrm{~m} \cdot \mathrm{s}^{-1}$, natomiast $\mathrm{w}$ dniach z pogodą radiacyjną prędkość w nocy jest mniejsza (około $1 \mathrm{~m} \cdot \mathrm{s}^{-1}$ ), a w ciągu dnia większa (do 2,5 $\mathrm{m}^{\cdot} \cdot \mathrm{s}^{-1}$ ) (ryc. 3).

Rezultaty badań przebiegu dobowego temperatury i wilgotności powietrza wewnątrz boru sosnowego zaprezentowano w tabelach ujmujących uśrednione wartości analizowanych elementów zarówno dla doby średniej z całego okresu badawczego, jak i dla dni z pogodą radiacyjną (tab. 1 i 2). Analiza przebiegu dobowego temperatury powietrza wewnątrz boru sosnowego na wyznaczonych wysokościach wskazuje na występowanie kilku charakterystycznych okresów, w których dochodzi do wyraźnego zmniejszenia bądź powiększania się różnic 


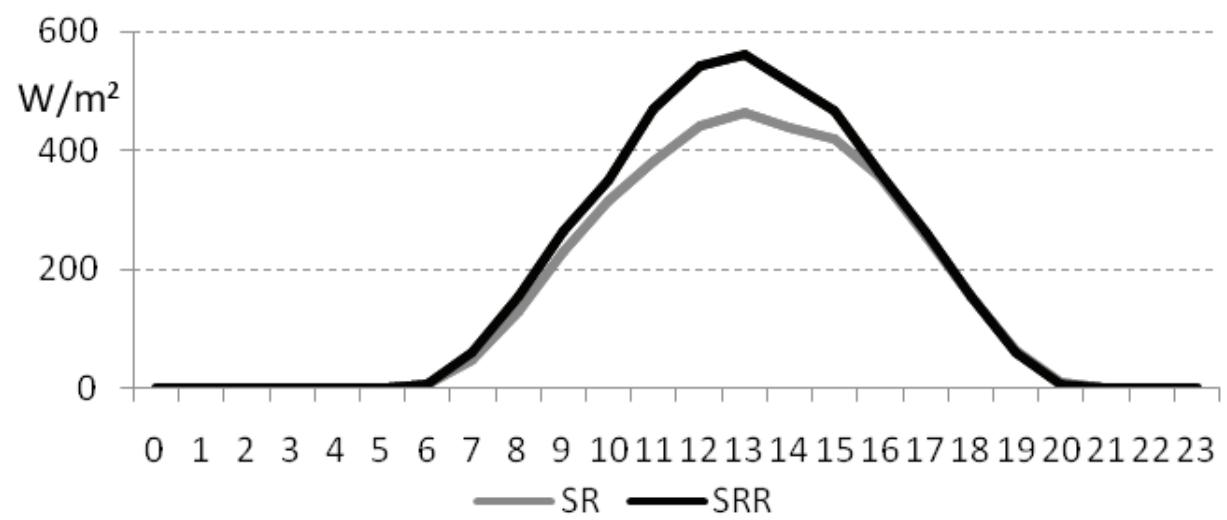

Ryc. 1. Przebieg natężenia całkowitego promieniowania słonecznego na stanowisku pomiarowym zlokalizowanym na wydmie szarej poza borem sosnowym dla średniej doby z okresu

2.07.2009-21.08.2009 (SR) oraz średniej doby z pogodą radiacyjną (SRR)

Fig. 1. Intensity of the total solar radiation (SR) at the measurement post located on the grey dune out of the coniferous forest, during the average day (SR) and for average day with the radiation weather from the period 2.07.2009-21.08.2009

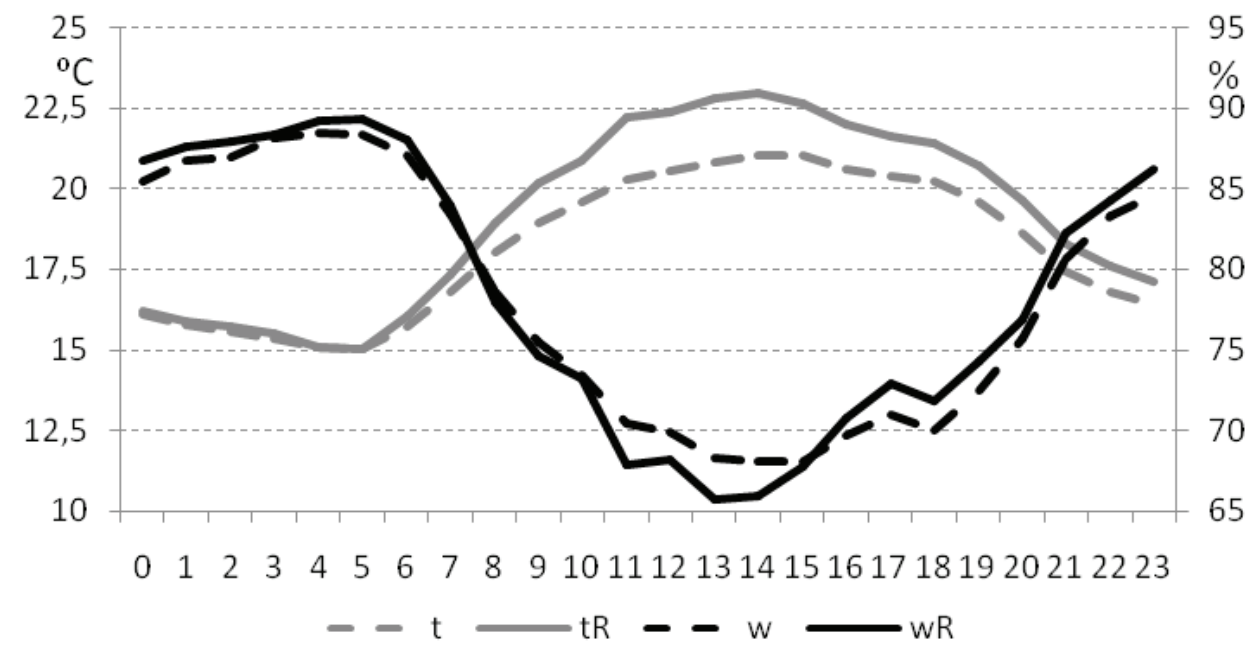

Ryc. 2. Przebieg temperatury powietrza na wysokości $2 \mathrm{~m}$ n.p.g. dla doby średniej $(t)$ i dla doby z pogodą radiacyjną $(t R)$ oraz wilgotności względnej powietrza na wysokości $2 \mathrm{~m}$ n.p.g. dla doby średniej $(w)$ i doby z pogodą radiacyjną $(w R)$ z okresu 2.07.2009-21.08.2009

Fig. 2. Daily average course of the air temperature at the height of $2 \mathrm{~m}$ above ground level for the average day $(t)$ and for the average day with the radiation weather $(t R)$, and the relative air humidity at the height of $2 \mathrm{~m}$ above ground level for the average day $(w)$ and for the day with the radiation weather $(w R)$ for the period 2.07.2009-21.08.2009 


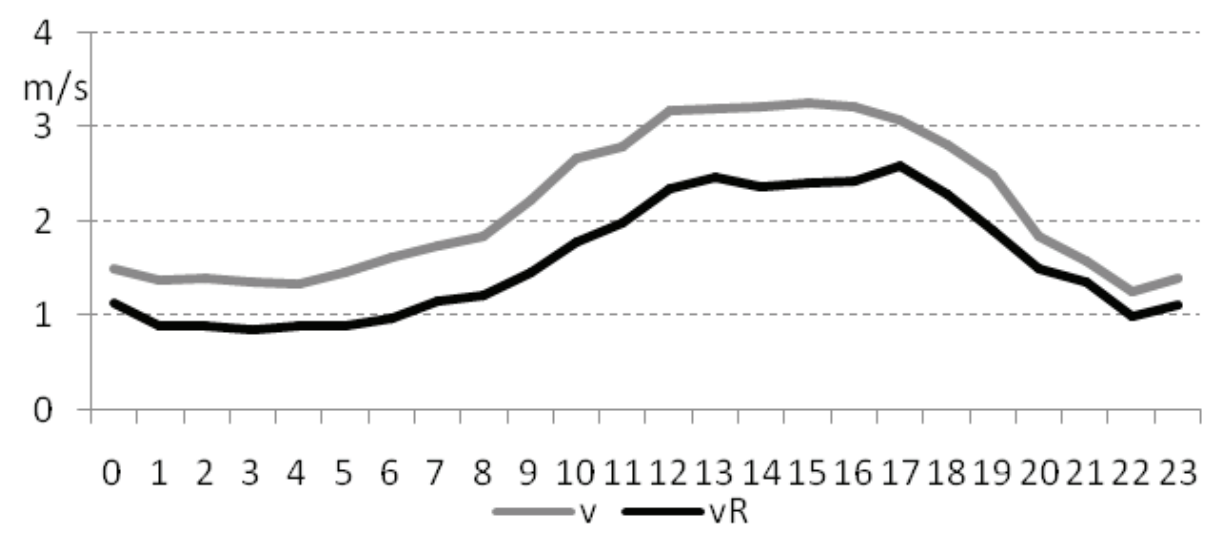

Ryc. 3. Przebieg prędkości wiatru na wysokości $4 \mathrm{~m}$ n.p.g. na przestrzeni otwartej dla doby średniej $(v)$ oraz doby średniej z pogodą radiacyjną $(v R)$ z okresu 2.07.2009-21.08.2009

Fig. 3. Daily average course of the wind speed at the height of $4 \mathrm{~m}$ above ground level at the open space for all days $(V)$ and for the days with the radiation weather $(V r)$ from the period 2.07.200921.08.2009

termicznych pomiędzy poszczególnymi piętrami lasu. Okresy te odnoszą się zarówno do dni z pogodą radiacyjną, jak i do warunków panujących w dobie średniej. Jednakże wyraźniejsze różnice termiczne oraz większe amplitudy dobowe temperatury charakteryzują dni z pogodą radiacyjną. Z tego powodu w niniejszym opracowaniu analizę badanego zjawiska oparto głównie na danych średnich z dni z pogodą radiacyjną. Również dołączone wykresy średniego dobowego przebiegu obu elementów meteorologicznych odnoszą się do wymienionej części okresu pomiarowego (ryc. 4 i 5).

$\mathrm{Z}$ analizy pola temperatury wnętrza boru sosnowego wynika, że od 15.00 do 8.00 najchłodniejsze jest powietrze zalegające w przygruntowej warstwie nad dnem boru, poniżej zwartych koron. Największe zróżnicowanie termiczne pomiędzy dnem boru a górnymi partiami koron, wynoszące od 0,5 do $0,8^{\circ} \mathrm{C}$, występuje od 22.00 do 7.00 rano, ponadto od 22.00 do 9.00 korony utrzymują najwyższą temperaturę w całym pionowym profilu badanego drzewostanu. Z kolei pomiędzy 9.00 i 14.00 temperatura $\mathrm{w}$ analizowanym profilu jest najbardziej wyrównana, z mogącymi pojawić się okresami najwyższych wartości w przygruntowej warstwie powietrza. Od 12.00 do 15.00 , w okresie największego natężenia promieniowania słonecznego, najwyższe wartości temperatury występują na $6 \mathrm{~m}$ n.p.g., a górne partie koron są najchłodniejsze w całym profilu pionowym boru sosnowego. Zjawisko to świadczy o przejęciu przez warstwę koron właśnie na omawianej wysokości $6 \mathrm{~m}$ n.p.g. roli powierzchni czynnej (Molga 1970).

Porównując wartości temperatury powietrza notowane na przestrzeni otwartej na standardowej wysokości $2 \mathrm{~m} \mathrm{n.p.g.} \mathrm{z} \mathrm{temperaturą} \mathrm{przygruntowej} \mathrm{warstwy}$ 
Tabela 1. Średnie wartości temperatury $\left[{ }^{\circ} \mathrm{C}\right]$ i wilgotności [\%] powietrza w okresie 2.07.2009-21.08.2009

Table 1. Mean temperature values $\left[{ }^{\circ} \mathrm{C}\right]$ and air humidity $[\%]$ in the period 2.07.2009-21.08.2009

\begin{tabular}{ccccccccccccc}
\hline $\begin{array}{c}\text { Godzina } \\
\text { Hour }\end{array}$ & $t$ & $t 1,5$ & $t 4$ & $t 6$ & $t 8$ & $t 10$ & $w$ & $w 1,5$ & $w 4$ & $w 6$ & $w 8$ & $w 10$ \\
\hline 0 & 16,1 & 16,2 & 16,4 & 16,4 & 16,5 & 16,6 & 85,4 & 88,1 & 88,3 & 87,5 & 87,0 & 86,7 \\
1 & 15,8 & 15,8 & 16,1 & 16,1 & 16,2 & 16,3 & 86,7 & 88,9 & 89,2 & 88,5 & 87,9 & 87,7 \\
2 & 15,6 & 15,6 & 15,9 & 15,9 & 16,0 & 16,1 & 86,9 & 89,4 & 89,6 & 88,9 & 88,3 & 88,1 \\
3 & 15,3 & 15,4 & 15,7 & 15,7 & 15,7 & 15,8 & 88,2 & 90,2 & 90,5 & 89,9 & 89,4 & 89,3 \\
4 & 15,1 & 15,2 & 15,4 & 15,4 & 15,5 & 15,6 & 88,5 & 90,9 & 91,1 & 90,4 & 90,0 & 89,8 \\
5 & 15,0 & 15,0 & 15,3 & 15,3 & 15,3 & 15,4 & 88,4 & 91,3 & 91,6 & 90,9 & 90,4 & 90,2 \\
6 & 15,7 & 15,2 & 15,4 & 15,4 & 15,5 & 15,7 & 87,0 & 91,0 & 91,4 & 90,7 & 90,2 & 89,6 \\
7 & 16,8 & 16,0 & 16,2 & 16,2 & 16,2 & 16,4 & 83,4 & 89,9 & 90,1 & 89,3 & 88,7 & 87,9 \\
8 & 18,0 & 17,1 & 17,1 & 17,1 & 17,1 & 17,4 & 78,6 & 86,8 & 87,3 & 86,4 & 86,1 & 85,0 \\
9 & 18,9 & 18,3 & 18,3 & 18,3 & 18,4 & 18,6 & 75,5 & 82,3 & 83,1 & 82,2 & 81,6 & 80,8 \\
10 & 19,6 & 19,4 & 19,3 & 19,2 & 19,3 & 19,3 & 73,4 & 78,5 & 79,6 & 78,9 & 78,0 & 78,3 \\
11 & 20,3 & 20,0 & 20,0 & 19,9 & 19,9 & 19,8 & 70,5 & 76,0 & 76,8 & 76,1 & 75,8 & 76,1 \\
12 & 20,5 & 20,4 & 20,4 & 20,4 & 20,4 & 20,2 & 69,9 & 74,9 & 75,6 & 74,6 & 74,6 & 75,0 \\
13 & 20,8 & 20,8 & 20,7 & 20,7 & 20,7 & 20,6 & 68,3 & 73,6 & 74,4 & 73,3 & 73,1 & 73,4 \\
14 & 21,0 & 21,1 & 21,0 & 21,0 & 21,0 & 20,9 & 68,1 & 72,3 & 73,1 & 72,1 & 71,9 & 72,2 \\
15 & 21,0 & 21,0 & 20,9 & 21,0 & 21,0 & 20,9 & 68,0 & 72,2 & 72,9 & 71,9 & 71,6 & 72,0 \\
16 & 20,6 & 20,7 & 20,7 & 20,7 & 20,8 & 20,7 & 69,7 & 73,2 & 73,7 & 72,9 & 72,4 & 72,8 \\
17 & 20,4 & 20,4 & 20,4 & 20,4 & 20,5 & 20,4 & 71,0 & 75,2 & 75,6 & 74,8 & 74,0 & 74,4 \\
18 & 20,2 & 20,1 & 20,1 & 20,1 & 20,1 & 20,2 & 70,0 & 74,7 & 75,3 & 74,5 & 74,1 & 73,8 \\
19 & 19,6 & 19,5 & 19,7 & 19,7 & 19,6 & 19,7 & 72,5 & 76,7 & 76,8 & 76,0 & 75,7 & 75,8 \\
20 & 18,6 & 18,7 & 18,9 & 18,9 & 18,8 & 18,9 & 75,7 & 79,6 & 79,5 & 78,5 & 78,3 & 78,0 \\
21 & 17,4 & 17,6 & 17,8 & 17,8 & 17,8 & 17,9 & 80,6 & 83,3 & 83,3 & 82,3 & 81,7 & 81,4 \\
22 & 16,8 & 16,8 & 17,1 & 17,1 & 17,2 & 17,3 & 83,3 & 85,8 & 85,7 & 84,9 & 84,3 & 84,0 \\
23 & 16,4 & 16,5 & 16,8 & 16,8 & 16,9 & 17,0 & 84,6 & 87,0 & 87,1 & 86,2 & 85,6 & 85,3 \\
\hline & & & & & & & & & & & & \\
\hline & & 15,4 &
\end{tabular}

Temperatura powietrza: $t$ - na zewnątrz boru sosnowego oraz w drzewostanie sosnowym $-t 1,5$ - na wysokości 1,5 m n.p.g., $t 4$ - na wysokości $4 \mathrm{~m}$ n.p.g., $t 6$ - na wysokości $6 \mathrm{~m}$ n.p.g., $t 8$ - na wysokości $8 \mathrm{~m}$ n.p.g, $t 10$ - na wysokości 10 m n.p.g. Wilgotność powietrza: $w$ - na zewnątrz boru sosnowego oraz w drzewostanie sosnowym $-w 1,5$ - na wysokości $1,5 \mathrm{~m}$ n.p.g., $w 4$ - na wysokości 4 m n.p.g., $w 6$ - na wysokości 6 m n.p.g., $w 8$ - na wysokości 8 m n.p.g., w 10 - na wysokości 
Tabela 2. Średnie wartości temperatury $\left[{ }^{\circ} \mathrm{C}\right]$ i wilgotności $[\%]$ powietrza $\mathrm{w}$ dniach z pogodą radiacyjną od 2.07.2009 do 21.08.2009

Table 2. Mean temperature values $\left[{ }^{\circ} \mathrm{C}\right]$ and air humidity $[\%]$ on days with radiant weather from 2 July 2009 until 21 August 2009

\begin{tabular}{ccccccccccccc}
\hline $\begin{array}{c}\text { Godzina } \\
\text { Hour }\end{array}$ & $t$ & $t 1,5$ & $t 4$ & $t 6$ & $t 8$ & $t 10$ & $w$ & $w 1,5$ & $w 4$ & $w 6$ & $w 8$ & $w 10$ \\
\hline 0 & 16,2 & 16,2 & 16,5 & 16,6 & 16,7 & 16,8 & 86,8 & 89,2 & 89,4 & 88,7 & 88,0 & 87,8 \\
1 & 15,9 & 16,0 & 16,3 & 16,3 & 16,4 & 16,5 & 87,6 & 89,8 & 90,0 & 89,3 & 88,6 & 88,5 \\
2 & 15,7 & 15,7 & 16,1 & 16,1 & 16,2 & 16,3 & 87,9 & 90,2 & 90,5 & 89,8 & 89,2 & 89,1 \\
3 & 15,5 & 15,5 & 15,9 & 15,9 & 16,0 & 16,1 & 88,3 & 90,5 & 90,8 & 90,2 & 89,7 & 89,6 \\
4 & 15,1 & 15,3 & 15,6 & 15,6 & 15,7 & 15,8 & 89,2 & 91,3 & 91,5 & 90,9 & 90,4 & 90,4 \\
5 & 15,0 & 15,1 & 15,4 & 15,4 & 15,5 & 15,7 & 89,3 & 91,7 & 91,8 & 91,1 & 90,6 & 90,4 \\
6 & 16,0 & 15,3 & 15,6 & 15,7 & 15,8 & 16,1 & 88,0 & 91,8 & 92,0 & 91,4 & 90,7 & 90,1 \\
7 & 17,3 & 16,4 & 16,6 & 16,6 & 16,7 & 17,0 & 84,0 & 90,7 & 90,8 & 90,1 & 89,2 & 88,3 \\
8 & 19,0 & 17,8 & 17,9 & 17,9 & 17,8 & 18,3 & 78,0 & 87,0 & 87,4 & 86,6 & 86,1 & 84,7 \\
9 & 20,2 & 19,5 & 19,5 & 19,5 & 19,5 & 19,9 & 74,6 & 81,7 & 82,5 & 81,7 & 80,9 & 79,9 \\
10 & 20,9 & 20,8 & 20,6 & 20,5 & 20,6 & 20,6 & 73,2 & 77,6 & 78,9 & 78,3 & 77,2 & 77,5 \\
11 & 22,2 & 21,7 & 21,7 & 21,7 & 21,6 & 21,6 & 67,8 & 74,1 & 74,9 & 74,3 & 73,9 & 74,3 \\
12 & 22,4 & 22,3 & 22,3 & 22,4 & 22,2 & 22,1 & 68,2 & 72,7 & 73,3 & 72,4 & 72,4 & 73,2 \\
13 & 22,8 & 22,8 & 22,7 & 22,8 & 22,7 & 22,6 & 65,8 & 70,5 & 71,3 & 70,1 & 70,1 & 70,6 \\
14 & 23,0 & 23,1 & 23,0 & 23,1 & 23,0 & 22,9 & 65,9 & 69,6 & 70,3 & 69,2 & 69,1 & 69,5 \\
15 & 22,7 & 22,7 & 22,8 & 22,8 & 22,8 & 22,6 & 67,7 & 70,6 & 71,1 & 70,2 & 69,9 & 70,5 \\
16 & 22,0 & 22,2 & 22,3 & 22,3 & 22,3 & 22,3 & 70,7 & 72,7 & 73,1 & 72,3 & 71,9 & 72,4 \\
17 & 21,6 & 21,7 & 21,8 & 21,8 & 21,9 & 21,8 & 72,9 & 76,0 & 76,2 & 75,6 & 74,8 & 75,2 \\
18 & 21,4 & 21,4 & 21,5 & 21,4 & 21,4 & 21,6 & 71,8 & 75,3 & 75,6 & 75,0 & 74,5 & 74,2 \\
19 & 20,7 & 20,7 & 20,9 & 20,8 & 20,8 & 20,8 & 74,3 & 78,2 & 78,0 & 77,4 & 77,0 & 77,2 \\
20 & 19,6 & 19,7 & 20,0 & 19,9 & 19,9 & 20,0 & 76,9 & 80,6 & 80,4 & 79,5 & 79,1 & 78,8 \\
21 & 18,3 & 18,5 & 18,8 & 18,8 & 18,8 & 18,8 & 82,2 & 84,0 & 83,9 & 83,1 & 82,4 & 82,2 \\
22 & 17,6 & 17,7 & 18,0 & 18,0 & 18,1 & 18,2 & 84,2 & 86,4 & 86,4 & 85,6 & 84,9 & 84,5 \\
23 & 17,1 & 17,3 & 17,6 & 17,6 & 17,7 & 17,9 & 86,2 & 88,1 & 88,2 & 87,4 & 86,7 & 86,3 \\
\hline
\end{tabular}

Temperatura powietrza: $t$ - na zewnątrz boru sosnowego oraz w drzewostanie sosnowym $-t 1,5$ - na wysokości $1,5 \mathrm{~m}$ n.p.g., $t 4$ - na wysokości $4 \mathrm{~m}$ n.p.g., $t 6$ - na wysokości $6 \mathrm{~m}$ n.p.g., $t 8$ - na wysokości $8 \mathrm{~m}$ n.p.g., $t 10$ - na wysokości 10 m n.p.g. Wilgotność powietrza: $w$ - na zewnątrz boru sosnowego oraz w drzewostanie sosnowym $-w 1,5$ - na wysokości $1,5 \mathrm{~m}$ n.p.g., $w 4$ - na wysokości 4 m n.p.g., $w 6$ - na wysokości 6 m n.p.g., $w 8$ - na wysokości 8 m n.p.g., $w 10$ - na wysokości $10 \mathrm{~m}$ n.p.g. 
powietrza we wnętrzu lasu można zauważyć od godziny 0.00 do 5.00 brak znaczących różnic termicznych $\left(\right.$ do $\left.0,1^{\circ} \mathrm{C}\right)$ pomiędzy przygruntową warstwą powietrza w terenie otwartym i borze sosnowym. Pomiędzy godzinami 6.00 i 11.00 najcieplejszą jest warstwa powietrza przy gruncie w terenie otwartym. Pomiędzy 12.00 i 14.00 następuje wyrównanie wartości temperatury między terenem otwartym i wnętrzem boru na wysokości około $6 \mathrm{~m}$ n.p.g. O 15.00 temperatury we wnętrzu boru na wysokości od 4 do $8 \mathrm{~m}$ n.p.g. są najwyższe zarówno w całym analizowanym profilu pionowym, jak i w porównaniu z przygruntową warstwą powietrza poza borem. Po tym czasie do godziny 23.00 najchłodniej jest $\mathrm{w}$ terenie otwartym lub różnica termiczna pomiędzy wnętrzem analizowanej formacji roślinnej a terenem niepokrytym roślinnością wysoką jest bardzo niewielka.

Analiza wilgotności powietrza we wnętrzu boru sosnowego, przeprowadzona zarówno dla doby średniej, jak i dla dni z pogodą radiacyjną, wykazuje istnienie wyraźnego zróżnicowania poszczególnych pięter lasu (ryc. 5).

Największą wilgotnością względną przez okres całej doby cechuje się dolna partia koron drzew na wysokości około $4 \mathrm{~m}$ n.p.g. Wilgotność na tym poziomie może osiągać od $70 \%$ około godziny 14.00 do ponad $90 \%$ o godzinie 6.00 . Cytowane wartości charakteryzują dni z pogodą radiacyjną. Najmniejsza wilgotność względna występuje na wysokości $10 \mathrm{~m}$ n.p.g. od godziny 20.00 do 6.00 , a od 7.00 do 19.00 najbardziej suche powietrze zalega na wysokości $8 \mathrm{~m} \mathrm{n.p.g.}$

Porównując wilgotność powietrza w borze sosnowym $\mathrm{z}$ wilgotnością powietrza na wysokości $2 \mathrm{~m}$ n.p.g. na przestrzeni otwartej, należy stwierdzić, że wnętrze analizowanej formacji roślinnej na każdej wysokości jest bardziej wilgotne niż powietrze poza lasem. Różnice nie są duże i mogą wynosić od kilku procent nocą do około 7 procent w godzinach okołopołudniowych.

\section{WNIOSKI KOŃCOWE}

Zauważone prawidłowości dotyczące zróżnicowania termicznego poszczególnych pięter boru sosnowego wskazują na przejęcie przez korony drzew roli powierzchni czynnej, jaką w terenie niepokrytym roślinnością pełni powierzchnia gleby. Świadczy o tym występowanie najwyższej wartości temperatury powietrza na wysokości około $6 \mathrm{~m}$ n.p.g. w godzinach od 12.00 do 15.00, czyli w okresie największego natężenia promieniowania słonecznego (Molga 1970). Ponadto zauważono, że od 15.00 do 8.00 najchłodniejsze jest dno lasu, poniżej zwartej warstwy koron przejmującej rolę powierzchni czynnej, co prawda przygruntowa inwersja temperatury jest zjawiskiem naturalnym $\mathrm{w}$ godzinach nocnych szczególnie nad ranem. Przy braku zwartej szaty roślinnej tworzy się w okresie spokojnych nocy i w godzinach porannych nad powierzchnią czynną (nad gruntem) na skutek wypromieniowania ciepła ze strefy przygruntowej 


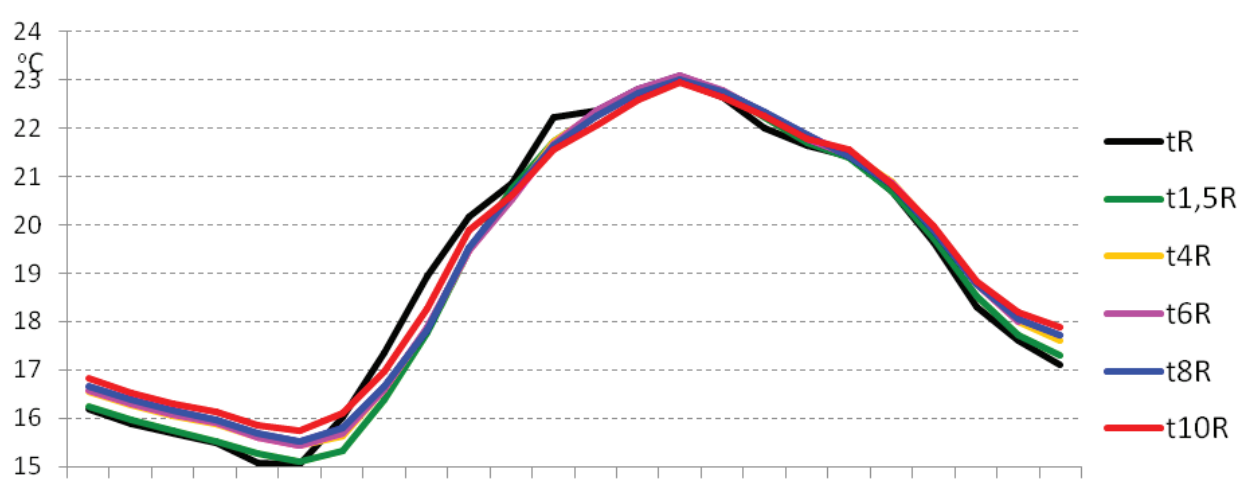

$\begin{array}{llllllllllllll}0 & 1 & 2 & 3 & 4 & 5 & 6 & 7 & 8 & 9 & 1011 & 121314151617181920212223\end{array}$

Ryc. 4. Przebieg temperatury powietrza wewnątrz boru sosnowego w dniach z pogodą radiacyjną na wysokości $1,5 \mathrm{~m}$ n.p.g. $(t 1 R), 4 \mathrm{~m}$ n.p.g. $(t 4 R), 6 \mathrm{~m}$ n.p.g. $(t 6 R), 8 \mathrm{~m}$ n.p.g. $(t 8 R)$ i $10 \mathrm{~m}$ n.p.g. $(t 10 R)$ oraz na przestrzeni otwartej na wysokości $2 \mathrm{~m} \mathrm{n.p.g.}(t R) \mathrm{w}$ okresie

\subsubsection{9-21.08.2009}

Fig. 4. Daily average course of the air temperature inside the pine forest on days with radiation weather at the height of $1,5 \mathrm{~m}$ above ground level $(t 1,5 R), 4 \mathrm{~m}$ above ground level $(t 4 \mathrm{R}), 6 \mathrm{~m}$ above ground level $(t 6 R), 8 \mathrm{~m}$ above ground level $(t 8 R), 10 \mathrm{~m}$ above ground level $(t 10 R)$ for the period 2.07.2009-21.08.2009

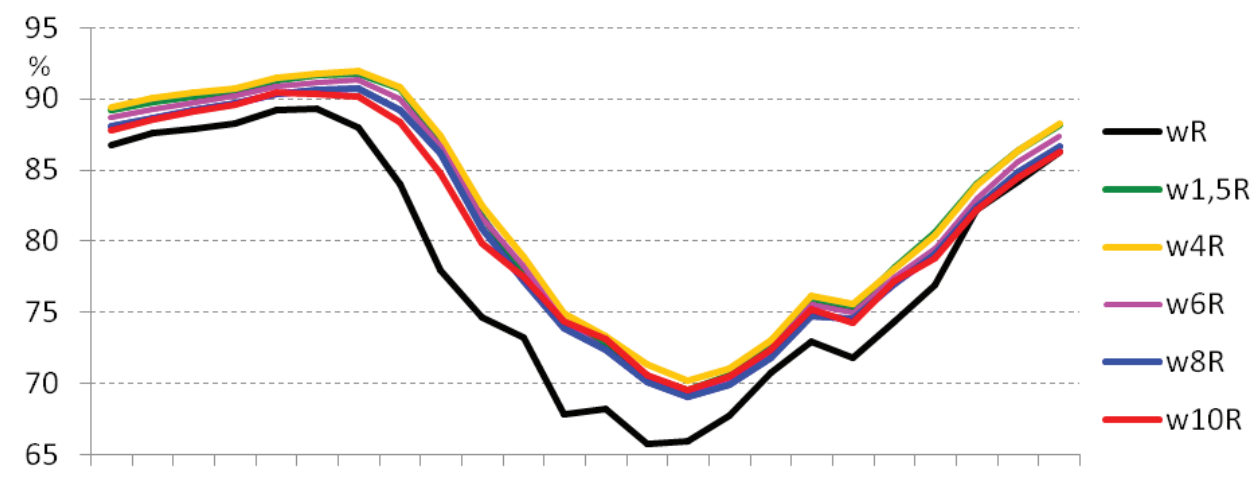

$\begin{array}{llllllllllll}0 & 1 & 2 & 3 & 4 & 5 & 6 & 7 & 8 & 9 & 1011 & 121314151617181920212223\end{array}$

Ryc. 5. Przebieg wilgotności względnej powietrza wewnątrz boru sosnowego w dniach z pogodą radiacyjną na wysokości $1,5 \mathrm{~m}$ n.p.g. $(w 1,5 R), 4 \mathrm{~m}$ n.p.g. $(w 4 R), 6 \mathrm{~m}$ n.p.g. $(w 6 R), 8 \mathrm{~m}$ n.p.g. (w8R) i $10 \mathrm{~m}$ n.p.g. (w10R) oraz na przestrzeni otwartej na wysokości $2 \mathrm{~m}$ n.p.g. (wR) w okresie 2.07.2009-21.08.2009

Fig. 5. Daily average course of the air relative humidity inside the pine forest on days with radiation weather at the height of $1,5 \mathrm{~m}$ above ground level $(w 1,5 R), 4 \mathrm{~m}$ above ground level $(w 4 R), 6 \mathrm{~m}$ above ground level $(w 6 R), 8 \mathrm{~m}$ above ground level $(w 8 R), 10 \mathrm{~m}$ above ground level $(w 10 R)$ and beside the forest on the open area on the high $2 \mathrm{~m}$ above ground level for the period 2.07.2009-21.08.2009 
w wyższe partie atmosfery. Wystąpienie wyraźnie chłodniejszej dolnej partii boru w godzinach okołopołudniowych od warstw leżących wyżej, na wysokości 6-8 m n.p.g. również jest dowodem na przejmowanie roli powierzchni czynnej przez korony sosen na tej właśnie wysokości (Molga 1970; Paszyński i in. 1999).

Różnice temperatury pomiędzy przestrzenią otwartą i wnętrzem lasu wskazują na zróżnicowanie procesów wymiany energii zależne od charakteru powierzchni czynnej. Obszar leśny charakteryzuje się wyraźnie mniejszą wartością albeda od obszaru wydmy szarej, na której usytuowano stację MAWS 201, co jest przyczyną pochłaniania większej ilości energii słonecznej w ciągu dnia. Ponadto, obszary leśne mogą gromadzić podczas dnia większą ilość ciepła, niż może być zmagazynowana w piaszczystej glebie pokrytej roślinnością trawiastą. Zmagazynowane ciepło, którego ilość zależy zarówno od pojemności cieplnej, jak i od albeda oddawane jest atmosferze w godzinach nocnych. W nocy na skutek emisji dodatkowej ilości ciepła z wysokiej szaty roślinnej oraz utrudnionej emisji energii z gleby leśnej w atmosferę ponad lasem (na skutek pochłaniania jej przez szatę roślinną) temperatura powietrza we wnętrzu lasu jest wyższa niż na przestrzeni pozbawionej szaty roślinnej (Geiger 1942; Molga 1970). W dzień grunt jest znacznie cieplejszy od leśnej powierzchni czynnej, co wynika z jego mniejszej pojemności cieplnej w porównaniu z obszarem boru sosnowego. $Z$ tego powodu wypromieniowuje znacznie więcej energii w postaci długofalowej niż bór, co przejawia się wyższą temperaturą powietrza nad gruntem podczas dnia (Paszyński i in. 1999). Wnętrze boru, a szczególnie warstwa powietrza zlokalizowane poniżej koron drzew w ciągu dnia jest z kolei chłodniejsze od obszarów pozbawionych szaty roślinnej z powodu znacznie osłabionego promieniowania słonecznego dochodzącego do dna lasu.

Rozkład wilgotności w poszczególnych piętrach badanego zbiorowiska leśnego nie odbiega znacząco od rezultatów badań tego problemu uzyskanych przez innych autorów. Większa zawartość pary wodnej w powietrzu wewnątrz lasu w porównaniu z przestrzenią otwartą wynika bezpośrednio z dużej intensywności parowania dolnej leśnej powierzchni czynnej. Utrzymywanie się największej wilgotności powietrza w dolnej strefie koron sosen jest najprawdopodobniej związane z ich dodatkową transpiracją (obok transpiracji roślinności dna lasu) oraz niewielkimi prędkościami wiatru, które pozwalają na gromadzenie się i utrzymywanie pary wodnej w tej właśnie strefie (Molga 1970).

\section{LITERATURA}

Bednorz E., Kolendowicz L., Szyga-Pluta K., 2001: Typy topoklimatu Słowińskiego Parku Narodowego. Dok. Geogr. nr 23, IgiPZ PAN, Współczesne badania topoklimatyczne. M. Kuchcik (red.), Warszawa, 19-32.

Bogucki J., 1994: Dobowa zmienność kierunku wiatru na Mierzei Łebskiej. Bad. Fizjogr. nad Pol. Zach., Ser. A - Geogr. Fiz., XLV, 5-23. 
Ceitel J., 1985: Zmiany mikroklimatu przygruntowej warstwy powietrza oraz mofrologii drzew ze wzrostem upraw sosnowych założonych w różnych więźbach początkowych. Roczn. Akad. Roln. w Poznaniu, CLX Leśnictwo, 21, 13-30.

Geiger R., 1942: Das Klima der Bodennahen Luftschicht. Die Wissenschaft BD78, Braunschweig.

Kolendowicz L., 2002: Zróżnicowanie temperatury, wilgotności względnej oraz wielkości ochładzającej powietrza w Stowińskim Parku Narodowym. Bad. Fizjogr. nad Pol. Zach., Ser. A Geogr. Fiz., t. 53, 83-93.

Kolendowicz L., Bednorz E., Szyga-Pluta K., 2004: Analysis of chosen cases of high daily rainfall at the local station of Climatology Department Adam Mickiewicz University in Poznan in Stowiński National Park. Ques., nr 23, 49-54.

Lewińska J., 2000: Klimat miasta. Zasoby, zagrożenia, ksztaltowanie. IGiPK, Kraków.

Łukasiewicz S., 2005: Temperatura i wilgotność powietrza w Ogrodzie Botanicznym UAM na tle wyników pomiarów stacji meteorologicznej Poznań Ławica. Bad. Fizjogr. nad Pol. Zach., Ser. A- Geogr. Fiz., 56, 83-92.

Medzińska M., 1991: Charakterystyka wielkości ochładzajacej powietrza w profilu Mierzei Łebskiej w okresie letnim 1988. Bad. Fizjogr. nad Pol. Zach., Ser. A - Geogr. Fiz., 37, 73-89.

Molga M., 1970: Meteorologia rolnicza. PWRiL, Warszawa.

Paszyński J., Miara K., Skoczek J., 1999: Wymiana energii między atmosfera a podtożem jako podstawa kartowania topoklimatycznego. Dok. Geogr. nr 14, IgiPZ PAN, Warszawa.

Rabski K., 1987: Wstępna charakterystyka termiczno-wilgotnościowa Mierzei Łebskiej. Bad. Fizjogr. nad Pol. Zach., Seria A - Geogr. Fiz., 42, 191-205.

Rabski K., 1992: Mezoklimatyczne tło obszaru Słowińskiego Parku Narodowego. Parki Narodowe i Rezerwaty Przyrody, t 11, nr 1.

Tamulewicz J., 2001: Prędkość wiatru w sezonie letnim w Stowińskim Parku Narodowym w obrębie Mierzei Łebskiej. Bad. Fizjogr. nad Pol. Zach., Ser A - Geogr. Fiz., 52, 149-159. 